\section{Coccidiosis in Japanese Quails (Coturnix japonica): Characterization of a Naturally Occurring Infection in a Commercial Rearing Farm ${ }^{1}$}

\section{ABSTRACT}

A study about coccidiosis in Japanese quails was carried out in order to identify species of the genus Eimeria and characterize a naturally occurring infection in a commercial rearing farm. For this purpose, fecal exams, oocyst counting and morphological study were performed, besides necropsy and histopathology to confirm diagnosis. Three species of the genus Eimeria were found and identified as E. tsunodai, E. uzura and $E$. bateri. The natural infection was characterized as subclinical because of the mild and nonspecific clinical signs. Nevertheless, coccidiosis was considered an important disease because endogenous stages of the parasites and a high number of oocysts in feces were associated with intestinal lesions. The results suggest that such infection might represent a limiting factor to this branch of the modern poultry industry.

\section{INTRODUCTION}

Quail production can be considered a branch of the modern poultry industry. Similar to the majority of animal production systems, it demands constant improvements on the application of new technologies and sanitary control. However, most studies have been published on Japanese quail nutrition (Garcia et al., 2002) and few have been done concerning quail diseases (Bigland et al., 1964). Among the avian diseases, coccidiosis affect bird development as well as production. Since quails are reared mostly in battery, there is no report in the literature on this disease, especially in this country.

Thus, this study presents an evaluation of coccidiosis in naturally infected Japanese quails from a commercial rearing farm.

\section{MATERIAL AND METHODS}

\section{Birds}

Japanese quails were reared in a farm located in the municipality of Seropédica, Rio de Janeiro, Brazil. There were approximately 27,000 birds in the farm, including young male and female quails (from 1 to 35 days of age) and mature females (above 35 days of age). Young birds were housed on litter bed and mature birds in cages for egg production.

\section{Fecal samples}

Pools of feces were collected from young and mature Japanese quails. A hundred young birds were placed into a plastic box $(1.5 \times 1.0 \mathrm{~m})$ for half an hour and feces samples were collected from the box. In the case of adult birds, feces were collected directly from the cages. Samples were placed into plastic bags and later processed at Laboratório de Coccídios e Coccidioses, Universidade Federal Rural do Rio de Janeiro. 
Teixeira M, Teixeira Filho WL, Lopes CWG

\section{Preparation of oocysts}

Samples were diluted into $2.5 \%$ aqueous potassium dichromate $\left(\mathrm{K}_{2} \mathrm{Cr}_{2} \mathrm{O}_{7}\right)$ and kept in Petri dishes for sporulation at room temperature. After sporulation, oocysts were recovered by centrifugation with saturated sugar solution as described by Duszynski \& Wilber (1997) and used in subsequent analysis.

\section{Morphological diagnosis and oocyst counting}

A Carl Zeiss binocular microscope with immersion objective (100x) and a K-15x PZO (Poland) micrometer was used for oocyst identification. The number of oocysts per gram of feces (OoPg) was determined according to the technique described by Menezes \& Lopes (1995).

\section{Necropsy}

Two birds were necropsied at the $3^{\text {rd }}, 5^{\text {th }}, 7^{\text {th }}, 14^{\text {th }}$, $21^{\text {st }}, 28^{\text {th }}, 35^{\text {th }}$ and $42^{\text {nd }}$ days after birth. Euthanasia was accomplished following Brazilian guidelines (Resolução n. ${ }^{\circ}$ 714, 20 th June, 2002, Conselho Federal de Medicina Veterinária). During necropsy, parts of the small intestine (jejunum and ileum) and caeca were taken for histopathology.

\section{Histological examination}

Histological examination was carried out to confirm the presence of developing stages of parasites within the intestine. Sections of $2 \mathrm{~cm}$ were excised from the small intestine and cecae of each bird, fixed in 10\% formaldehyde solution, processed and stained by hematoxilin-eosin or periodic acid Schiff (PAS), accordind to Behmer et al. (1976). For sequencial examinations, a triocular JENAMED, Carl Zeiss-Jena microscope with 40x objective was used.

\section{Statistical analysis}

Oocysts measurements were analyzed using the software Excel (Microsoft ${ }^{\circledR}$ ) for averages and standard deviation.

\section{Photographs}

Pictures were made using a digital camera CD Mavica MVC-CD250 Sony ${ }^{\circledR}$, and a photographic camera f-KAS Automatic-2 with film ISO 100 (21 DINA) (Kodak, Mexico).

\section{RESULTS AND DISCUSSION}

\section{Species of the genus Eimeria}

Three species of the genus Eimeria (Figure 1, A, B and $C$ ) previously reported affecting Japanese quails
Coccidiosis in Japanese Quails (Coturnix japonica): Characterization of a Naturally Occurring Infection in a Commercial Rearing Farm

(Teixeira \& Lopes, 2002) were identified in the present study, as follows:

a. Eimeria tsunodai Tsutsumi, 1972: Sporulated oocysts were ovoid, measuring $20.2 \pm 1.5$ by $14.88 \pm$ $0.79 \mu \mathrm{m}$ and 1.36 shape index. Oocyst wall was smooth, double layered, with brownish inner layer and colorless outer layer, and measured $0.99 \pm 0.1 \mu \mathrm{m}$. Despite usually only one polar granule was present, it could appear in pairs and refractive. Micropyle and residual body of the oocyst were absent. The sporocysts varied from ovoid to ellipsoid and measured $10.41 \pm$ 0.6 by $5.39 \pm 0.3 \mu \mathrm{m}$. They had a finer end where a small and fainted Stieda body projected. The residual body of the sporocyst was present and dispersed among the sporozoites, which were in pairs with globules visible at the enlarged extremity.

b. Eimeria uzura Tsunoda \& Muraki, 1971: Sporulated oocysts were ovoid, measuring $22.2 \pm 6.76$ by $16.16 \pm 1.13 \mu \mathrm{m}$, and 1.32 shape index. Oocyst wall was smooth, double layered, with brownish inner layer and colorless outer layer, measuring $1.08 \pm 0.12 \mu \mathrm{m}$. Two to five polar granules were observed in the oocysts, sometimes with a massive aspect, but not refractive). The micropyle and residual body of the oocysts were absent. The sporocysts were ovoid measuring $11.76 \pm 0.74$ by $5.94 \pm 0.45 \mu \mathrm{m}$, with a finer end, where a piriform Stieda body projected. The residual body of the sporocysts was present and had concentric granules between the sporozoites, which had refractive globules at the enlarged extremity.

c. Eimeria bateri Bathia, Pandey \& Pande, 1965: Sporulated oocysts were subspherical, ovoid or ellipsoid, measuring $21.50 \pm 1.84$ by $16.36 \pm 1.32 \mu \mathrm{m}$ and shape index 1.32. Oocyst wall was smooth, double layered, with brownish inner layer and colorless outer layer, measuring $0.99 \pm 0.1 \mu \mathrm{m}$. A single and refractive polar granule was present, but micropyle and the residual body of the oocyst were absent. Sporocysts were ovoid and measured $10.35 \pm 0.73$ by $6.66 \pm 0.58 \mu \mathrm{m}$, with a prominent knob-like Stieda body. The residual body of the sporocyst was dispersed among the sporozoites, which had refractive globules at the enlarged extremity.

Descriptions of Eimeria date from the beginning of the last century, and ever since means for an appropriate characterization and identification of the species have been discussed. Several parameters can be used (Long \& Joyner, 1984) and new methods have 
Teixeira M, Teixeira Filho WL, Lopes CWG
Coccidiosis in Japanese Quails (Coturnix japonica): Characterization of a Naturally Occurring Infection in a Commercial Rearing Farm been developed (Kucera \& Reznicky, 1991; Daugschies et al., 1999; Gruber \& Fernandez, 1999; Pereira et al., 2001). However, morphological differentiation associated to specificity factors is still useful. Duszynski \& Wilber (1997) emphasized and encouraged precision in the description of species, and established basic characteristics for an appropriate description of the oocysts. However, accuracy and caution were already recommended by Bandoni \& Duszynski (1988). In the present study, species previously described were found, and the final identification was carried out by comparison with the original descriptions of the parasites. Some Eimeria species with similar morphology were initially excluded because of the differences in the size of the oocysts. The measurements, in the beginning of the investigation, the measurements allowed to distinguish from closely related species. Initially, E. coturnicis (Chakravarty \& Kar, 1947), E. tahamensis (Amoudi, 1987) and E. fluminensis (Teixeira \& Lopes, 2002) were excluded. Despite the similar measurements, E. taldykurganica (Svambaev \& Utebaeva, 1973) did not fit with the descriptions because it has a very different form, essentially ellipsoid with shape index 1.86. Lastly, $E$. dispersa (Tyzzer, 1929) may infect $C$. coturnix but is not infective to $C$. japonica (Tsunoda \& Muraki, 1971) and therefore was also dismissed. On the other hand, E. tsunodai, E. uzura and E. bateri were identified in the present study based on the measurements and other features of oocysts, such as polar granules, Stieda body and refractive globules, which were essential to confirm identification.

\section{Clinical signs and Gross lesions}

During the first week of life, few young quails presented diarrhea, weakness and small blood spots in the upper small intestine (jenunum and ileum). Later, softening of feces at the $14^{\text {th }}$ day and an increased cecum were seen in quails necropsied at the $21^{\text {st }}$ days. From the $35^{\text {th }}$ to the $42^{\text {nd }}$ days, a significant number of quails had diarrhea, which disappeared soon.

There are few reports about the pathogenicity of Eimeria in quails. Mazurkiewiewicz et al. (1967) reported clinical signs such as lack of appetite, ruffled feathers, uncoordinated movements, inhibition of laying and loss of weight in naturally infected young and mature quails reared at the laboratory. Norton \& Pierce (1971) infected young Japanese quails experimentally with E. bateri and observed mild loss of weight and, although anorexia and softening of feces were observed at the third day of infection, the disease was considered mild and easy to overcome. Tsunoda \& Muraki (1971) also reported low pathogenicity in Japanese quails experimentally infected with $1 \times 10^{5}$ oocysts of $E$. uzura, observing diarrhea and anemia from the $5^{\text {th }}$ to $8^{\text {th }}$ day of infection. No mortality was not reported in these researches, and disease was considered similar to coccidiosis caused by E. acervulina in chickens. Later, Ruff \& Fagan (1984) used pure and mixed cultures of $E$. uzura to infect quails. They reported mortality, lower weight gain and poor reproductive performance. Concerning weight gain, E. tsunodai was considered more pathogenic than E. bateri. Finally, when pathogenicity was investigated, the authors suggested that young quails are more susceptible to the coccidiosis effects. The results in the present work corroborate such opinion, since clinical signs were seen only in young quails. Finally, coccidiosis was assumed to be characteristically subclinical in this rearing farm with nonspecific and very mild clinical signs when the whole period of study was considered.

\section{Histological Observations}

Endogenous stages of the parasites were found in the small intestine. These were usually located in the villi, mainly above the nucleus of apical epithelial cells, or in the medium portion close to the glands (Figure 1, $\mathrm{D}$ and $\mathrm{E})$. These observations resemble those described by Tsunoda \& Muraki (1971), Norton \& Pierce (1971) and Tsutsumi (1972) not only because of the site of infection, but also morphology was similar. Thus, endogenous stages observed in the small intestine were assumed to be developmental stages of $E$. bateri and $E$. uzura, while the species found in the cecae might be $E$. tsunodai.

Pathological changes were also observed in the mucosa of the small intestine. Villous erosion (Figure $1, F$ and $G$ ), frequently concomitant with hyperplasia of the crypts of Lieberkühn, was often observed, as well as inflamatory infiltrate characterized by the presence of granulocytes and mononuclear cells, usually associated with edema.

The colonisation of the gastrointestinal tract causes structural and functional changes, since the presence of parasites induces both general and local disturbances. Detailed information on such pathological effects can be obtained from previous reviews of coccidiosis in poultry (Levine, 1982; Soulsby, 1987). A common feature of the infection is a severe depression of the digestive and absortive capabilities of the mucosa. Furthermore, the magnitude of all 
disturbances and functional changes are usually related to the intensity of the parasitic infection.

\section{CONCLUSION}

Three species of the genus Eimeria were found and identified as E. bateri, E. tsunodai and E. uzura; and the natural infection was characterized as subclinical. Despite of causing mild and nonspecific clinical signs, coccidiosis was considered an important disease because endogenous stages of the parasites and a high number of oocysts in feces were associated with intestinal lesions. The results strongly suggest that such infection might represent a limiting factor for quail production.

\begin{tabular}{|c|c|c|c|c|c|c|c|c|c|c|}
\hline \multirow{2}{*}{ Species } & \multirow{2}{*}{ Author } & \multirow{2}{*}{ Host } & \multicolumn{2}{|c|}{ Oocyst } & \multirow{2}{*}{ S.I. a } & \multirow{2}{*}{ W all } & \multirow{2}{*}{$\begin{array}{l}\text { Polar } \\
\text { Granule }\end{array}$} & \multicolumn{2}{|r|}{ Sporocyst } & \multirow{2}{*}{$\begin{array}{l}\text { Stieda } \\
\text { Body }\end{array}$} \\
\hline & & & shape & size $(\mu \mathrm{m})$ & & & & shape & size $(\mu \mathrm{m})$ & \\
\hline E. uzura & Tsunoda Muraki, 1971 & C. japonica & $\begin{array}{l}\text { ellipsoidal-ovoid } \\
\text { ovoid* }\end{array}$ & $\begin{array}{c}18.75-29.0 \times 15.0-22.75 \\
18.86-22.76 \times 15.04-17.42 *\end{array}$ & $\begin{array}{l}1.31 \\
1.32 *\end{array}$ & $\begin{array}{l}\text { double } \\
\text { double* }\end{array}$ & $\begin{array}{l}0-4 \\
2-4^{*}\end{array}$ & $\begin{array}{l}? \\
\text { ovoid * }\end{array}$ & $11.02-12.5$ ? $5.49-6.39$ * & $\stackrel{?}{\text { piriform }}$ \\
\hline E. tsunodai & Tsutsumi, 1972 & C.japonica & $\begin{array}{l}\text { ovoid } \\
\text { ovoid* }\end{array}$ & $\begin{array}{c}15.5-22.5 \times 16.5-18.5 \\
18.7-21.7 \times 14.09-15.67 *\end{array}$ & $\begin{array}{l}1.30 \\
1.36^{*}\end{array}$ & double & $\begin{array}{l}0-5 \\
1-2 *\end{array}$ & $\stackrel{?}{\text { ovoid* }}$ & $\begin{array}{c}10.3-11.5 \times 5.0-6.1 \\
9.81-11.01 \times 5.09-5.69 \text { * }\end{array}$ & $\begin{array}{l}\text { fainted } \\
\text { fainted* }\end{array}$ \\
\hline E. bateri & Bathia et al.,1965 & C. japonica* ${ }^{*}$ & $\begin{array}{l}\text { ellipsoidal, ovoid } \\
\text { or subspherical } \\
\text { ellipsoidal, ovoid } \\
\text { or subspherical }\end{array}$ & $\begin{array}{c}15.0-28.0 \times 14.0-23.0 \\
19.66-23.34 \times 15.04-17.68 *\end{array}$ & $\begin{array}{l}1.26 \\
1.32 *\end{array}$ & double* & $\begin{array}{c}1 \\
1^{*}\end{array}$ & $\begin{array}{l}\text { ovoid } \\
\text { ovoid* }\end{array}$ & $\begin{array}{c}9.0-13.0 \times 5.0-8.0 \\
9.66-11.8 \times 6.08-7.24 *\end{array}$ & $\begin{array}{l}\text { prominent } \\
\text { prominent } \\
\text { nipple-like* }\end{array}$ \\
\hline E. fluminensis & Teixe ira e Lopes, 2002 & C. japonica & subspherical & $15.44-19.18 \times 14.73-18.17$ & 1.05 & double & $?$ & ovoid & $9.32-11.53 \times 5.34-6.5$ & piriform \\
\hline E. dispersa & Tyzzer, 1929 & C. coturnix & ovoid & $17.2-26.4 \times 15.4-22.4$ & $?$ & single & $?$ & ovoid & $?$ & $?$ \\
\hline E. coturnicis & Chakravarty Kar, 1967 & C. coturnix & ovoid & $26.4-38.8 \times 19.8-26.4$ & $?$ & double & 1 & ovoid & $13.2-17.2 \times 8.8-11.0$ & knob-like \\
\hline E. taldykurganica & Svambaev Utebaeva, 1973 & C. coturnix & ovoid & $21.88-25.40 \times 11.9-13.1$ & 1.86 & double & 1 & ovoid & $8.1-11.6-3.59-4.8$ & ? \\
\hline E. tahamensis & Amoudi, 1987 & C.delegorguey & ellipsoidal & $36.5-42.0 \times 25.5-29.0$ & ? & double & 1 & ovoid & $14.0-16.0 \times 9.0-11.5$ & knob-like \\
\hline
\end{tabular}

(*) present work; (a) shape index; (?) unknown.

\section{REFERENCES}

Amoudi MA. Eimeria tahamensis n. sp. (Apicomplexa: Eimeriidae) from the Arabian quail (Coturnix delegorguey arabica). Journal of Parasitology 1987; 34:455-456.

Bandoni SM, Duszynsnki DW. A plea for improved presentation of type material for coccidia. Journal of Parasitology 1988; 74:519523.

Bathia BB, Pandey TP, Pande BP. Eimeria bateri n. sp. from Indian common quail (Coturnix coturnix). Indian Journal of Microbiology 1965; 5:61-64.

Behmer AO, Tolosa EMC, Neto AGF. Manual de Técnicas para histologia normal e patológica. São Paulo: EDART, Editora da Universidade de São Paulo; 1976.

Bigland CH, Da Massa AJ, Woodard AE. Diseases of Japanese quail (Coturnix coturnix japonica) - A flock survey and experimental transmission of selected avian pathogens. Poultry Science 1964;13:212-219.

Chakravarty M, Kar AB. A study on the coccidian of Indian birds. Proceedings of the Royal Society of Edinburgh 1947; 62:225-233.

Daugschies A, Imarom S, Bollwahn, W. Differentiation of porcine Eimeria spp. by morphologic algorithms. Veterinary Parasitology 1999; 81:201-210.

Duszynski DW, Wilber PG. A guideline for the preparation of species descriptions in the Eimeriidae. Journal of Parasitology 1997; 83: 333-336.

Garcia EA, Mendes AA, Pizzolante CC, Veiga N, Mattos TK. Alimentação de codornas com milho moído e ração de postura no período pós-jejum durante a muda forçada e seus efeitos sobre o desempenho. Revista Brasileira de Ciência Avícola 2002; 4:119126.

Gruber A, Fernandez S. Recentes avanços na biologia molecular de protozoários do gênero Eimeria. In: II Simpósio Internacional sobre coccidiose aviária; 1999; Foz do Iguaçu, PR. Brasil. p. 9-21.

Kucera J, Reznicky M. Diferentiation of species of Eimeria from the fowl using a computerized image analysis system. Folia Parasitologica 1991; 38:107-113.

Levine ND. Protozoan Parasites of Domestic animals and of man. 2 ed. Minneapolis: Burgess Pub. Co; 1982.

Long PL, Joyner LP. Problems in the identification of species of Eimeria. Journal of Protozoology 1984; 31:535-541.

Mazurkiewicz M, Podlewska D, Wachnik Z. Kokcydioza u przepiórek japonskich. Medycyna Weterynaryjna 1967; 23:536-537.

Menezes RCA, Lopes CWG. Epizootiologia da Eimeria arloingi em caprinos na microrregião Serrana Fluminense, Rio de Janeiro, Brasil. Revista da Universidade Federal Rural do Rio de Janeiro 1995; 17: 5-12.

Norton CC, Pierce MA. The life cycle of Eimeria bateri (Protozoa: Eimeriidae) in the Japanese quail Coturnix japonica. Journal of Protozoology 1971; 18:57-62.

Pereira MJS, Fonseca AH, Lopes CWG. Regressão linear na caracterização de variações morfométricas em coccidia. Revista Brasileira de Parasitologia Veterinária 2001; 10:75-78.

Ruff MD; Fagan JM. Pathogenicity of Japanese Quail (Coturnix japonica). Poultry Science, 1984, 63:55-60. 
Soulsby EJL. Parasitologia y enfermedades parasitarias em los animales domésticos. 7 ed. México: Nueva Editorial Interamericana; 1987.

Svambaev SK, Utebaeva MK. Coccidial infections of Phasianus cochicus mongolicus and Coturnix coturnix in Kazakhstan. Izvestiia Akademii Nauk SSSR. Seriia biologicheskaia 1973; 6:62-68.

Teixeira M, Lopes CWG. Species of the genus Eimeria (Apicomplexa: Eimeriidae) from Japanese quails (Coturnix japonica) in Brazil and E. fluminensis for the preoccupied E. minima of this quail. Revista Brasileira de Ciências Veterinárias 2002; 9:53-56.

Tsunoda L, Muraki Y. A new coccidium of Japanese quails: Eimeria uzura n. sp. Japanese Journal of Veterinary Science 1971; 33: 227235.

Tsutsumi Y. Eimeria tsunodai n.sp. (Protozoa:Eimeriidae). A cecael coccidium of Japanese quails (Coturnix japonica). Japanese Journal of Veterinary Science 1972; 34:1-9.

Tyzzer EE. Coccidiosis in gallinaceous birds. American Journal of Hygiene 1929; 10:269-383. 
Teixeira M, Teixeira Filho WL, Lopes CWG
Coccidiosis in Japanese Quails (Coturnix japonica): Characterization of a Naturally Occurring Infection in a Commercial Rearing Farm
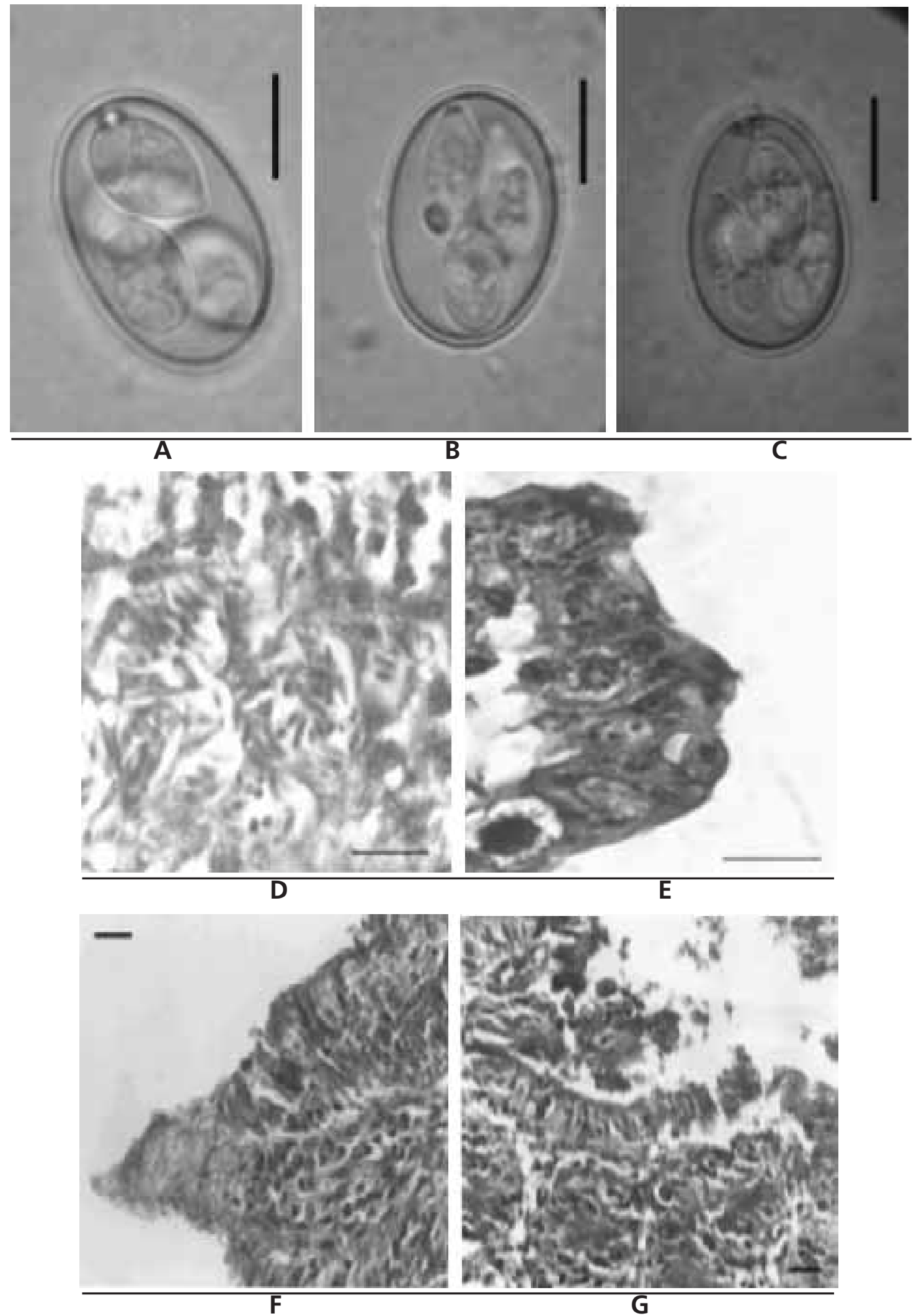

Figure 1 - Sporulated oocysts of (A) Eimeria bateri, (B) E. tsunodai and (C) E. uzura (in saturated sugar solution); Caeca of Japanese quail at the $42^{\text {nd }}$ days, (D) Schizonts with merozoites and ileum at the $14^{\text {th }}$ days, (E) macro and microgamonts, HE; Jejunum of Japanese quail at the $14^{\text {th }}$ days with (F) villous and (G) epithelial erosion, HE; (scale bar $=10 \mu \mathrm{m}$ ). 